Article

\title{
Ecosystem Services Assessment and Valuation of Atmospheric Magnesium Deposition
}

\author{
Garth R. Groshans ${ }^{1}$, Elena A. Mikhailova ${ }^{1, *}$, Christopher J. Post ${ }^{1}$, Mark A. Schlautman ${ }^{2} \mathbb{1}$, \\ Michael P. Cope ${ }^{1}$ and Lisha Zhang ${ }^{3}$ \\ 1 Department of Forestry and Environmental Conservation, Clemson University, Clemson, SC 29634, USA \\ 2 Department of Environmental Engineering and Earth Sciences, Clemson University, Anderson, \\ SC 29625, USA \\ 3 Agricultural Sciences Department, Clemson University, Clemson, SC 29634, USA \\ * Correspondence: eleanam@clemson.edu; Tel.: +1-864-656-3535
}

Received: 26 June 2019; Accepted: 24 July 2019; Published: 27 July 2019

\begin{abstract}
Ecosystem services (ES) often rely on biogeochemical cycles, but values associated with abiotic services are often ignored or underestimated. Ecosystem services from atmospheric magnesium $\left(\mathrm{Mg}^{2+}\right)$ deposition are abiotic flows (wet, dry, and total), which can be considered a source of naturally-occurring fertilizer and liming material, have not been included in economic valuations of ecosystem services. Market-based valuation of these atmospheric ecosystem service flows can partially address this negative externality. This study assessed the value of wet, dry, and total atmospheric magnesium deposition flows in the contiguous United States (USA) within boundary-based administrative accounts (e.g., state, region) based on data from the National Atmospheric Deposition Program (NRSP-(3), and the market price of human-derived material (agricultural dolomite, $\left.\mathrm{CaMg}\left(\mathrm{CO}_{3}\right)_{2}\right)$. The total supporting ecosystem value of atmospheric magnesium deposition flows was $\$ 46.7 \mathrm{M}$ (i.e., 46.7 million U.S. dollars) ( $\$ 18.5 \mathrm{M}$ wet $+\$ 28.2 \mathrm{M}$ dry) based on an average 2014 price of $\$ 12.90$ per U.S. ton of agricultural dolomite $\left(\mathrm{CaMg}\left(\mathrm{CO}_{3}\right)_{2}\right)$. The atmosphere is a common-pool resource that plays an important role in the pedosphere, providing important abiotic ES, but its monetary value is often not identified in the market due to a lack of information and/or knowledge of the proper valuation method. This study demonstrates one approach to translate atmospheric magnesium deposition flows entering the soil as an abiotic ES and potential monetary values at various scales. Omission of abiotic services in ES analysis can lead to an incomplete economic valuation.
\end{abstract}

Keywords: dolomite; fertility; food security; replacement cost method; stock; value

\section{Introduction}

The Millennium Ecosystem Assessment [1] is based on an ecosystem services framework, which is widely used in connection with the United Nations (UN) Sustainable Development Goals (SDGs) [2,3]. Ecosystem services are defined as "the benefits people obtain from ecosystems," which include provisioning (e.g., food, fiber, etc.), regulating (e.g., climate regulation, etc.), cultural (e.g., recreation, etc.), and supporting (e.g., maintenance of life cycles, etc.) [2,3]. Ecosystem services often rely on biogeochemical cycles, but the values associated with these ecosystem services are often ignored or underestimated [3-5]. An example of an ecosystem service provided by biogeochemical cycles is the provision of magnesium, which is a life-supporting nutrient (Table 1). Society relies on natural and human-derived stocks and flows of magnesium, which requires a system-based approach to its ES valuation [6,7]. A "system" is defined as a set of connected processes ("flows") and quantities of resources ("stocks") [6,7]. 
Table 1. Connections between ecosystem services and selected Sustainable Development Goals (SDGs) in relation to atmospheric magnesium deposition (adapted from Wood et al., 2017 [3]).

\begin{tabular}{ccc}
\hline $\begin{array}{c}\text { TEEB Ecosystem Service } \\
\text { Categories }\end{array}$ & TEEB Typology & $\begin{array}{c}\text { Sustainable Development Goals } \\
\text { (SDGs) }\end{array}$ \\
\hline Provisioning & Resources & SDG 2, 3, 12, 13, 15 \\
Regulating & Maintenance of soil fertility & SDG 2, 3, 12, 13, 15 \\
Supporting & Maintenance of life cycles & SDG 2, 3, 12,13,15 \\
\hline
\end{tabular}

Note: The Economics of Ecosystems and Biodiversity (TEEB). SDG 2 "Zero Hunger", SDG 3 "Good Health and Well-Being", SDG 12 "Responsible Consumption and Production." SDG 13 "Climate Action", SDG 15 "Life on Land."

Atmospheric magnesium deposition flows (wet, dry, and total) provide goods and ecosystem services, which are important for achieving the SDGs to sustain global human societies [8].

Atmospheric magnesium deposition flows are significant and valuable sources of $\mathrm{Mg}^{2+}$, which is an essential nutrient [9]. The significance of $\mathrm{Mg}^{2+}$ in the environment and agriculture (especially as a soil nutrient) is well documented [10], and the following examples are directly linked to the selected SDGs $-2,3,12,13$, and 15 (listed below) [1]:

SDG 2. End hunger, achieve food security and improve nutrition and promote sustainable agriculture.

Magnesium is not only an essential nutrient for human beings, but also an essential macronutrient for plant and animal nutrition [9]. Plants utilize magnesium for forming and utilizing ATP, activating enzymes, and photosynthesis; however, there is an international concern about low magnesium levels in the soil [11]. The magnesium content in plant-based foods is dependent on the amount of plant-available magnesium in the soil [12]. Magnesium is the seventh most abundant element in the Earth's crust, but most of it is incorporated in the crystal structure of minerals, thus it is not directly available for plant uptake [10]. Atmospheric magnesium wet deposition is an important source of soluble magnesium, especially in the coastal areas since seawater is enriched in magnesium [13].

SDG 3. Ensure healthy lives and promote well-being for all at all ages.

Magnesium is an essential nutrient and electrolyte for human health and well-being; however, global magnesium deficiency is in the range of 50-99\% according to dietary reference intakes (DRIs) set by the United States and Canada $[12,14]$. Furthermore, $\mathrm{Mg}^{2+}$ deficiency can be attributed to an inadequate consumption of plant-based foods such as nuts, whole grains, and green vegetables, which can result in related diseases [12,14]. It would require at least 3192 metric tons/day of magnesium to ensure that every person is able to meet their daily magnesium requirement with a global population of 7.6 billion people, and a recommended daily intake of $420 \mathrm{mg}$ per person per day of magnesium [15]. In terms of monetary value, it will cost nearly $\$ 45,000 /$ day based on a 2014 average price of $\$ 12.90$ per U.S. ton of agricultural dolomite $\left(\mathrm{CaMg}\left(\mathrm{CO}_{3}\right)_{2}\right)$ [16].

SDG 12. Ensure sustainable consumption and production patterns.

Agricultural benefits from the atmospheric magnesium $\left(\mathrm{Mg}^{2+}\right)$ deposition flows (wet, dry, and total), which can be considered a naturally-occurring liming and fertilizer materials, have not been included in economic valuations of ecosystem services. Market-based valuation of these atmospheric ecosystem service flows can partially address this negative externality in order to "achieve the sustainable management and efficient use of natural resources" [8].

SDG 13. Take urgent action to combat climate change and its impacts.

Atmospheric $\left(\mathrm{Mg}^{2+}\right)$ deposition flows play an important role in climate regulation and carbon sequestration (e.g., pedogenic carbonate formation) [17].

SDG 15. Protect, restore and promote sustainable use of terrestrial ecosystems, sustainably manage forests, combat desertification and halt and reverse land degradation and biodiversity loss.

Atmospheric magnesium contributes to the increases in the $\mathrm{pH}$ of rainwater, and can counteract the effects of acid deposition on ecosystems (especially in the forest ecosystems) because of its buffering capacity [18]. Draaijers et al. (1997) [19] reported that 50\% of the potential acid deposition was 
counteracted by deposition of non-sea salt $\mathrm{Mg}^{2+}$ in the southern European forests. Magnesium is also important in the grassland ecosystems with soil-magnesium depletion linked to overgrazing [10]. Watmough et al. (2014) [20] described the importance of atmospheric magnesium deposition for preventing soil acidification in the Athabasca Oil Sands Region of Canada.

Magnesium ions in soils are naturally sourced from either atmospheric deposition (Table 2), or as a primarily abiotic lithosphere resource [21] from the weathering of primary minerals such as ferromagnesian minerals (e.g., olivine, mica, amphibole, and pyroxene), secondary minerals such as clays (e.g., montmorillonite, vermiculite, and chlorite) or carbonates (magnesite, dolomite, talc, and serpentine group) $[9,22]$. These processes that occur in the pedosphere and lithosphere are critical, but often ignored in ES frameworks because they are viewed as being dominated by abiotic services [21,23]. Atmospheric deposition of $\mathrm{Mg}^{2+}$ similarly is mostly an abiotic service with potential economic value.

Table 2. Lithosphere-pedosphere-atmosphere-biosphere ecosystem services exchange, stocks, goods, flows (represented by arrows) in relation to magnesium and its availability for use in the biosphere (e.g., plant removal).

\begin{tabular}{ccc}
\hline Lithosphere & Pedosphere & Atmosphere \\
\hline Abiotic-Biotic & Biotic-Abiotic & Abiotic-Biotic \\
Mineral stock & Soil-based stock & Atmospheric stock \\
$\left(\mathrm{Mg}^{2+}\right.$ in primary & $\left(\mathrm{Mg}^{2+}\right.$ in soil & $\left(\mathrm{Mg}^{2+}\right.$ in \\
minerals) & solution) & deposition) \\
Not available & Slowly available & Readily available \\
\hline & Biosphere (e.g., plant removal, etc.) \\
& Biotic & \\
\hline
\end{tabular}

Typically, slow weathering rates of primary and secondary minerals cannot provide adequate amounts of $\mathrm{Mg}^{2+}$ for annual crop production, while $\mathrm{Mg}^{2+}$ ions within or on the exchange sites of clay minerals supply a slow release to the soil [9]. Soils with $\mathrm{Mg}^{2+}$ deficiencies are typically amended with the application of either dolomitic limestone (raises soil $\mathrm{pH}$ ), agricultural Epsom salts (no increase in soil $\mathrm{pH})$, basic slag, or animal manure [24]. Dolomite $\left(\mathrm{CaMg}\left(\mathrm{CO}_{3}\right)_{2}\right)$, a common amendment for $\mathrm{Mg}^{2+}$ deficiencies, is comprised of approximately $6-20 \% \mathrm{Mg}^{2+}$, which varies by the geologic setting in which it was formed [9].

Groshans et al. (2018) [15] used market-based analysis of atmospheric total magnesium deposition, but this analysis was limited in scope since atmospheric magnesium deposition consists of multiple flows (Figure 1). These flows can be measured as separate constituent stocks (e.g., annual mean wet $\mathrm{Mg}^{2+}$ deposition or annual mean dry $\mathrm{Mg}^{2+}$ deposition in $\mathrm{kg} / \mathrm{ha}$ ) or composite (total) stock (e.g., annual mean total $\mathrm{Mg}^{2+}$ deposition in $\mathrm{kg} / \mathrm{ha}$ ) (Figure 1). In addition, these flows can be measured within science-based boundaries (e.g., soil order, etc.), and/or administrative boundaries (e.g., country, state, region, etc.), and evaluated based on different human-derived substitutes (e.g., agricultural dolomite $\left(\mathrm{CaMg}\left(\mathrm{CO}_{3}\right)_{2}\right)$ if soil $\mathrm{pH}$ needs to be raised, or Epsom salts (magnesium sulfate heptahydrate) if soil $\mathrm{pH}$ does not need to be raised). For example, soil $\mathrm{pH}$ tends to be low across much of the eastern third of the USA and also in western Washington, western Oregon and northern California. Comparison of the soil $\mathrm{pH}$ map against the magnesium deposition maps (Figure 1) shows that most of the atmospheric deposition of magnesium coincides with these low soil $\mathrm{pH}$ regions. So only in the West and Midwest regions of the USA would farmers likely apply Epsom salt instead of dolomitic limestone when soil magnesium levels are too low. 


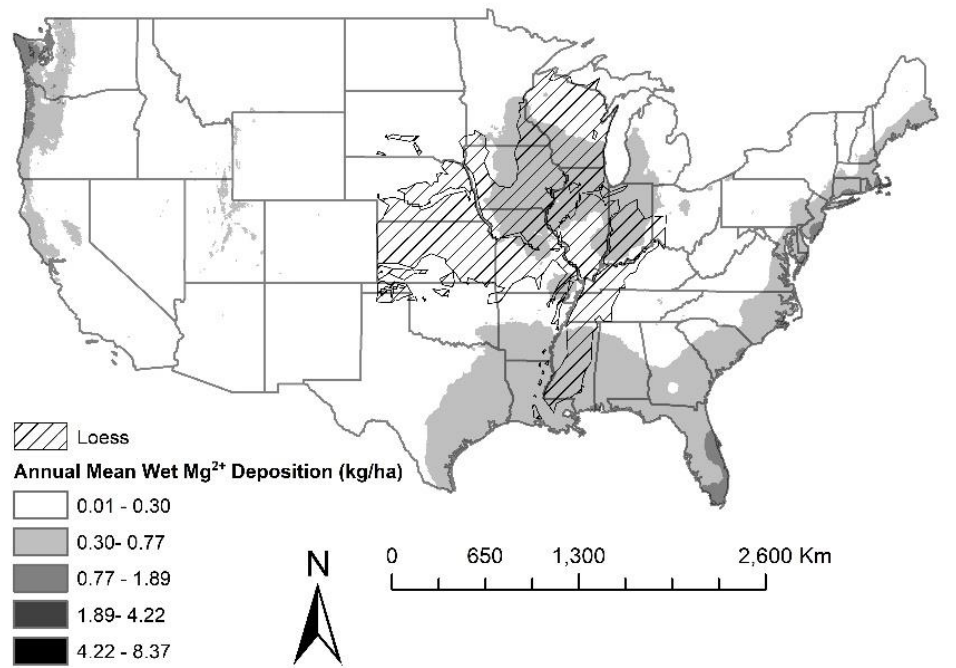

(a)

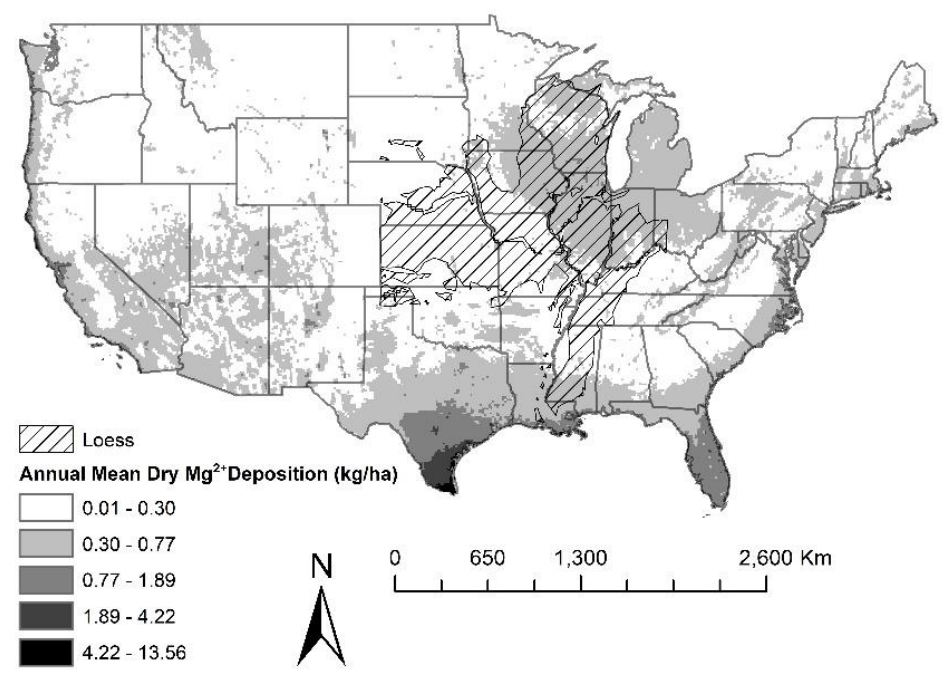

(b)

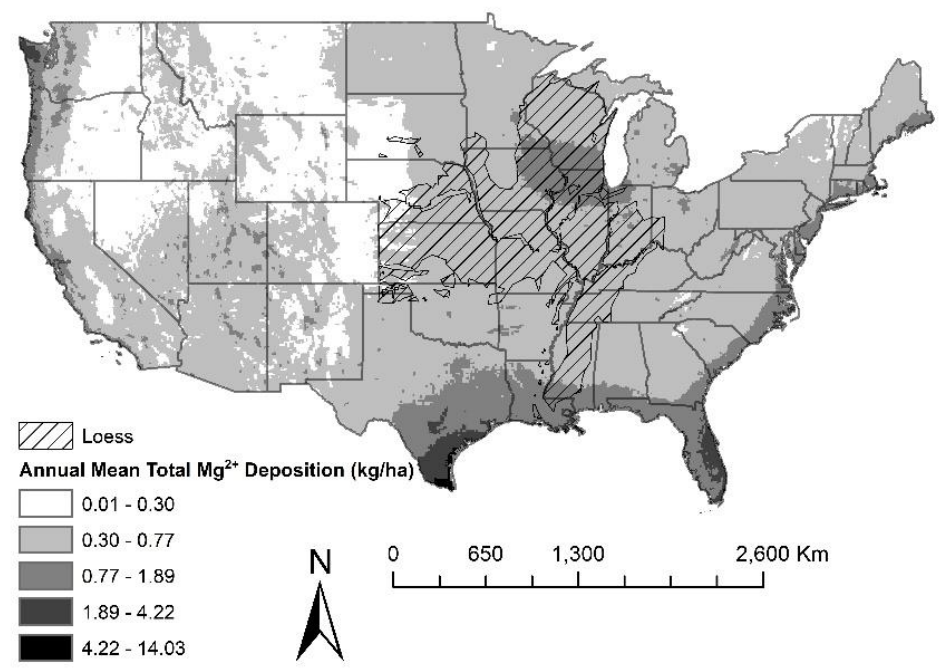

(c)

Figure 1. Area-normalized annual mean $\mathrm{Mg}^{2+}$ deposition ( $\mathrm{kg} / \mathrm{ha}$ ) for the years 2000 to 2015 in the contiguous United States: (a) wet, (b) dry, and (c) total (adapted from Groshans et al. 2018 [15]). 
In the example provided in Table 3 (based on data from Goddard et al. (2007) [17]), mean atmospheric wet magnesium deposition is evaluated as a separate constituent flow on the basis of a human-derived substitute: agricultural dolomite (raises soil $\mathrm{pH}$ ).

The soil orders with the highest total mean value of wet atmospheric $\mathrm{Mg}^{2+}$ deposition based on a national average price (2014) of $\$ 12.90$ per U.S. ton of agricultural dolomite $\left(\mathrm{CaMg}\left(\mathrm{CO}_{3}\right)_{2}\right)$ ranked: (1) Mollsiols (\$3.99M), (2) Alfisols (\$3.88M), and (3) Ultisols (\$3.02M). The soil orders with the highest area-normalized total mean value of wet atmospheric $\mathrm{Mg}^{2+}$ deposition $\left(\$ \mathrm{ha}^{-1}\right)$ ranked: (1) Andisols $\left(\$ 0.06 \mathrm{ha}^{-1}\right)$, Histosols $\left(\$ 0.05 \mathrm{ha}^{-1}\right)$, and Spodosols $\left(\$ 0.04 \mathrm{ha}^{-1}\right)$ (Table 3). Mollisols and Alfisols, common soil orders of the breadbasket regions, ranked 1st and 2nd, respectively, for total mean value of wet atmospheric $\mathrm{Mg}^{2+}$ deposition; however, Mollisols ranked 8th and Alfisols ranked 6th for U.S. dollar price per hectare (Table 3).

Table 3. Example of valuation within science-based boundaries: soil order. Total value of mean, and area-normalized annual atmospheric wet $\mathrm{Mg}^{2+}$ deposition by soil order for the 10-year period 1994 to 2003 [17] based on a 2014 average price of $\$ 12.90$ per U.S. ton of agricultural dolomite $\left(\mathrm{CaMg}\left(\mathrm{CO}_{3}\right)_{2}\right.$ [16]).

\begin{tabular}{|c|c|c|c|}
\hline \multirow{2}{*}{ Soil Order } & \multirow{2}{*}{ Total Area (ha) } & \multicolumn{2}{|c|}{ Based on Average Price of Dolomite } \\
\hline & & Mean Value (\$ ha $\left.{ }^{-1}\right)$ & Total Value (\$) \\
\hline \multicolumn{4}{|c|}{ Slight weathering } \\
\hline Entisols & $9.2 \times 10^{7}$ & 0.02 & $1.83 \times 10^{6}$ \\
\hline Inceptisols & $6.0 \times 10^{7}$ & 0.03 & $1.62 \times 10^{6}$ \\
\hline Histosols & $6.8 \times 10^{6}$ & 0.05 & $3.67 \times 10^{5}$ \\
\hline Gelisols & - & - & - \\
\hline Andisols & $5.9 \times 10^{6}$ & 0.06 & $3.56 \times 10^{5}$ \\
\hline \multicolumn{4}{|c|}{ Intermediate weathering } \\
\hline Aridisols & $7.8 \times 10^{7}$ & 0.01 & $9.39 \times 10^{5}$ \\
\hline Vertisols & $1.5 \times 10^{7}$ & 0.04 & $5.39 \times 10^{5}$ \\
\hline Alfisols & $1.3 \times 10^{8}$ & 0.03 & $3.88 \times 10^{6}$ \\
\hline Mollisols & $1.8 \times 10^{8}$ & 0.02 & $3.99 \times 10^{6}$ \\
\hline \multicolumn{4}{|c|}{ Strong weathering } \\
\hline Spodosols & $2.6 \times 10^{7}$ & 0.04 & $9.82 \times 10^{5}$ \\
\hline Ultisols & $9.1 \times 10^{7}$ & 0.03 & $3.02 \times 10^{6}$ \\
\hline Oxisols & - & - & - \\
\hline tals or averages & $6.9 \times 10^{8}$ & 0.03 & $1.75 \times 10^{7}$ \\
\hline
\end{tabular}

Note: Total areas and thus subsequent calculated values for Oxisols and Gelisols were negligible and therefore are not shown.

Monetary valuation of atmospheric magnesium deposition by soil order within the contiguous USA has limited application to decision making, because most decisions are made within administrative boundaries. The objective of this study is to conduct ecosystem services valuation of various (wet, dry, and total) atmospheric magnesium deposition flows within the contiguous United States (USA) by different spatial aggregation levels (e.g., country, state, and region) using the State Soil Geographic (STATSGO) soil database.

\section{Materials and Methods}

\subsection{The Accounting Framework}

Atmospheric magnesium deposition (flow) from atmospheric capital into soil capital represents the amount of magnesium defined in a spatial and temporal context, which is the quantity of magnesium deposition (kg) per area (ha) per unit time (year) (Figure 1). Table 4 provides a conceptual overview of the accounting framework for valuation of various atmospheric magnesium deposition flows: wet, dry, and total. 
Table 4. Conceptual overview of the accounting framework for a systems-based approach in the ecosystem services valuation of various atmospheric magnesium deposition flows used in this study (adapted from [25]).

\begin{tabular}{|c|c|c|c|c|}
\hline $\begin{array}{l}\text { Biophysical } \\
\text { Accounts } \\
\text { (Science-Based) }\end{array}$ & $\begin{array}{l}\text { Administrative } \\
\text { Accounts } \\
\text { (Boundary-Based) }\end{array}$ & Monetary Accounts & Benefit & Total Value \\
\hline $\begin{array}{l}\text { Science-based } \\
\text { extent: }\end{array}$ & $\begin{array}{l}\text { Administrative } \\
\text { extent: }\end{array}$ & $\begin{array}{l}\text { Ecosystem good(s) and } \\
\text { service(s): }\end{array}$ & Sector: & Types of value: \\
\hline \multicolumn{5}{|c|}{$\begin{array}{l}\text { Separate constituent flow 1: Annual mean atmospheric wet } \mathrm{Mg}^{2+} \text { deposition } \\
\text { Separate constituent flow 2: Annual mean atmospheric dry } \mathrm{Mg}^{2+} \text { deposition } \\
\text { flow (sum of constituent flows: wet }+ \text { dry): Annual mean atmospheric total } \mathrm{Mg}^{2+} \text { deposition }\end{array}$} \\
\hline - Not determined & $\begin{array}{l}\text { - Country } \\
\text { - State } \\
\text { - Region }\end{array}$ & $\begin{array}{c}\text { Abiotic goods and services: } \\
-\mathrm{Mg}^{2+} \text { in wet, dry } \\
\text { deposition } \\
\text { Services: } \\
\text { - Provisioning (e.g., food) } \\
\text { - Supporting (e.g., nutrient } \\
\text { cycling) } \\
\text { - Others }\end{array}$ & $\begin{array}{c}\text { Agriculture: } \\
\text { - Liming equivalent } \\
\text { (e.g., pH buffering) } \\
\text { - Fertilizer } \\
\text { equivalent } \\
\text { (e.g., } \mathrm{Mg}^{2+} \text { as an } \\
\text { essential nutrient) }\end{array}$ & $\begin{array}{c}\text { Market valuation using } \\
\text { replacement cost method } \\
\text { based on market-based } \\
\text { value of commodities: } \\
\text { - Price of agricultural } \\
\text { dolomite }\left(\mathrm{CaMg}\left(\mathrm{CO}_{3}\right)_{2}\right) \\
\text { [12] if soil pH needs to be } \\
\text { raised }\end{array}$ \\
\hline
\end{tabular}

\subsection{The Monetary Valuation}

Annual mean atmospheric $\mathrm{Mg}^{2+}$ deposition $\left(\mathrm{kg}^{2} \cdot \mathrm{ha}^{-1}\right)$ maps (National Atmospheric Deposition Program, NRSP-(3) for the years 2000-2015 (Table 5) were computed together into single raster layers for wet, dry and total atmospheric $\mathrm{Mg}^{2+}$ deposition concentrations using the Cell Statistics spatial analyst tool in ArcGIS ${ }^{\circledR} 10.4$ (ESRI, Redlands, CA, USA) [26]. The Zonal Statistics spatial analyst tool in ArcGIS ${ }^{\circledR} 10.4$ was then used to create a Microsoft Excel table with the appropriate raster data for each boundary (states, and regions). The Microsoft Excel tables for wet, dry and total atmospheric $\mathrm{Mg}^{2+}$ deposition in each boundary was converted to U.S. dollars per area (i.e., hectare) and total U.S. dollars using the following equations:

$$
\begin{gathered}
\$ / h a=\left(\mathrm{Mg}^{2+} \text { deposition, } \mathrm{kg} / \mathrm{ha}\right) \times \frac{184.4 \mathrm{~kg} \mathrm{CaMg}\left(\mathrm{CO}_{3}\right)_{2}}{24.305 \mathrm{~kg} \mathrm{Mg}{ }^{2+}} \times \frac{1 \mathrm{lb}_{m}}{0.45359 \mathrm{~kg}} \times \frac{1 \mathrm{U} . \mathrm{S} . \mathrm{ton}}{2000 \mathrm{lb} m} \times \\
\frac{\$ \text { price ton } \mathrm{CaMg}\left(\mathrm{CO}_{3}\right)_{2}}{\text { U. }} \\
\$=(\text { price per area from eqn. } 1) \times(\text { area in } \mathrm{ha})
\end{gathered}
$$

For each boundary, monetary values in U.S. dollars represent the amount of money required to replace the $\mathrm{Mg}^{2+}$ from atmospheric deposition with agricultural dolomite $\left(\mathrm{CaMg}\left(\mathrm{CO}_{3}\right)_{2}\right)$ based on a national average price (2014) of $\$ 12.90$ per U.S. ton (e.g., the replacement cost method) [16]. However, the monetary values are not inclusive of additional costs such as expenses associated with initially mining the dolomite, transportation (e.g., fuel), equipment, and labor it would take for an external application of the dolomite [15,25].

\section{Results and Discussion}

\subsection{The Value of Annual Mean Wet $\mathrm{Mg}^{2+}$ Deposition at the Country Scale by State, Region (2000-2015)}

The total provisioning ecosystem value of atmospheric wet magnesium deposition flows was $\$ 18.5 \mathrm{M}$ (i.e., 18.5 million U.S. dollars). The states with the highest total value of wet atmospheric $\mathrm{Mg}^{2+}$ deposition ranked: (1) Oklahoma (\$4.64M), (2) Texas (\$1.82M), and (3) Florida (\$1.01M) (Table 6). The states with the highest area-normalized total mean value of wet atmospheric $\mathrm{Mg}^{2+}$ deposition $\left(\$ \mathrm{ha}^{-1}\right.$ ) ranked: (1) Florida $\left(\$ 0.07 \mathrm{ha}^{-1}\right),(2)$ Connecticut $\left(\$ 0.06 \mathrm{ha}^{-1}\right)$, and (3) New Jersey $\left(\$ 0.06 \mathrm{ha}^{-1}\right)$ (Table 6). The hydrosphere is the greatest source of biologically-available $\mathrm{Mg}^{2+}$ ions; therefore, Texas, Florida, Louisiana, Connecticut and New Jersey likely have the highest wet atmospheric $\mathrm{Mg}^{2+}$ deposition due to each state bordering a body of water [14]. Florida ranked $1^{\text {st }}$ for U.S. dollar per hectare of wet atmospheric $\mathrm{Mg}^{2+}$ deposition, which could be due to Florida's vast shoreline and close proximity to the ocean. 
Table 5. Annual mean atmospheric $\mathrm{Mg}^{2+}$ deposition for each state (region) for the 16-year period 2000 to 2015. Note that some total values do not exactly equal the sum of their corresponding wet plus dry values due to roundoff errors.

\begin{tabular}{|c|c|c|c|c|}
\hline State (Region) & $\begin{array}{l}\text { Area } \\
\text { (ha) }\end{array}$ & $\begin{array}{l}\text { Mean Wet } \mathrm{Mg}^{2+} \\
\left(\mathrm{kg} \mathrm{ha}^{-1}\right)\end{array}$ & $\begin{array}{c}\text { Mean Dry Mg } \mathrm{Mg}^{2+} \\
\left(\mathrm{kg} \mathrm{ha}^{-1}\right)\end{array}$ & $\begin{array}{l}\text { Mean Total } \mathrm{Mg}^{2+} \\
\left(\mathrm{kg} \mathrm{ha}^{-1}\right)\end{array}$ \\
\hline Connecticut & $1.28 \times 10^{6}$ & 0.58 & 0.35 & 0.93 \\
\hline Delaware & $5.24 \times 10^{5}$ & 0.54 & 0.42 & 0.96 \\
\hline Massachusetts & $2.08 \times 10^{6}$ & 0.46 & 0.42 & 0.87 \\
\hline Maryland & $2.48 \times 10^{6}$ & 0.36 & 0.35 & 0.71 \\
\hline Maine & $8.26 \times 10^{6}$ & 0.26 & 0.27 & 0.53 \\
\hline New Hampshire & $2.38 \times 10^{6}$ & 0.24 & 0.23 & 0.47 \\
\hline New Jersey & $1.93 \times 10^{6}$ & 0.58 & 0.41 & 0.99 \\
\hline New York & $1.25 \times 10^{7}$ & 0.21 & 0.23 & 0.44 \\
\hline Pennsylvania & $1.17 \times 10^{7}$ & 0.23 & 0.29 & 0.52 \\
\hline Rhode Island & $2.61 \times 10^{5}$ & 0.56 & 0.44 & 1.00 \\
\hline Vermont & $2.49 \times 10^{6}$ & 0.17 & 0.21 & 0.38 \\
\hline West Virginia & $6.28 \times 10^{6}$ & 0.20 & 0.33 & 0.53 \\
\hline (East) & $5.22 \times 10^{7}$ & 0.27 & 0.29 & 0.55 \\
\hline Iowa & $1.46 \times 10^{7}$ & 0.34 & 0.37 & 0.71 \\
\hline Illinois & $1.46 \times 10^{7}$ & 0.33 & 0.42 & 0.75 \\
\hline Indiana & $9.43 \times 10^{6}$ & 0.35 & 0.35 & 0.70 \\
\hline Michigan & $1.50 \times 10^{7}$ & 0.26 & 0.36 & 0.62 \\
\hline Minnesota & $2.18 \times 10^{7}$ & 0.24 & 0.26 & 0.50 \\
\hline Missouri & $1.81 \times 10^{7}$ & 0.30 & 0.24 & 0.53 \\
\hline Ohio & $1.07 \times 10^{7}$ & 0.27 & 0.35 & 0.62 \\
\hline Wisconsin & $1.45 \times 10^{7}$ & 0.28 & 0.39 & 0.68 \\
\hline (Midwest) & $1.19 \times 10^{8}$ & 0.29 & 0.33 & 0.63 \\
\hline Arkansas & $1.37 \times 10^{7}$ & 0.30 & 0.28 & 0.58 \\
\hline Louisiana & $1.18 \times 10^{7}$ & 0.48 & 0.70 & 1.18 \\
\hline Oklahoma & $1.81 \times 10^{7}$ & 0.24 & 0.25 & 0.49 \\
\hline Texas & $6.83 \times 10^{7}$ & 0.25 & 0.75 & 1.00 \\
\hline (South Central) & $1.12 \times 10^{8}$ & 0.28 & 0.61 & 0.88 \\
\hline Alabama & $1.34 \times 10^{7}$ & 0.38 & 0.28 & 0.66 \\
\hline Florida & $1.43 \times 10^{7}$ & 0.66 & 0.98 & 1.63 \\
\hline Georgia & $1.52 \times 10^{7}$ & 0.34 & 0.31 & 0.65 \\
\hline Kentucky & $1.04 \times 10^{7}$ & 0.23 & 0.23 & 0.46 \\
\hline Mississippi & $1.23 \times 10^{7}$ & 0.39 & 0.33 & 0.73 \\
\hline North Carolina & $1.26 \times 10^{7}$ & 0.35 & 0.43 & 0.78 \\
\hline South Carolina & $7.96 \times 10^{6}$ & 0.41 & 0.33 & 0.74 \\
\hline Tennessee & $1.09 \times 10^{7}$ & 0.25 & 0.23 & 0.48 \\
\hline Virginia & $1.03 \times 10^{7}$ & 0.25 & 0.29 & 0.54 \\
\hline (Southeast) & $1.07 \times 10^{8}$ & 0.37 & 0.40 & 0.77 \\
\hline Colorado & $2.70 \times 10^{7}$ & 0.11 & 0.23 & 0.34 \\
\hline Kansas & $2.13 \times 10^{7}$ & 0.20 & 0.21 & 0.41 \\
\hline Montana & $3.81 \times 10^{7}$ & 0.10 & 0.16 & 0.26 \\
\hline North Dakota & $2.00 \times 10^{7}$ & 0.18 & 0.21 & 0.39 \\
\hline Nebraska & $2.00 \times 10^{7}$ & 0.17 & 0.18 & 0.35 \\
\hline South Dakota & $2.00 \times 10^{7}$ & 0.17 & 0.18 & 0.35 \\
\hline Wyoming & $2.53 \times 10^{7}$ & 0.10 & 0.18 & 0.28 \\
\hline (Northern Plains) & $1.72 \times 10^{8}$ & 0.14 & 0.19 & 0.33 \\
\hline Arizona & $2.94 \times 10^{7}$ & 0.10 & 0.35 & 0.44 \\
\hline California & $4.08 \times 10^{7}$ & 0.13 & 0.41 & 0.53 \\
\hline Idaho & $2.16 \times 10^{7}$ & 0.11 & 0.17 & 0.28 \\
\hline New Mexico & $3.15 \times 10^{7}$ & 0.09 & 0.29 & 0.38 \\
\hline Nevada & $2.87 \times 10^{7}$ & 0.06 & 0.27 & 0.33 \\
\hline Oregon & $2.51 \times 10^{7}$ & 0.19 & 0.23 & 0.41 \\
\hline Utah & $2.20 \times 10^{7}$ & 0.16 & 0.32 & 0.47 \\
\hline Washington & $1.74 \times 10^{7}$ & 0.27 & 0.21 & 0.49 \\
\hline (West) & $2.17 \times 10^{8}$ & 0.13 & 0.29 & 0.42 \\
\hline Totals or averages & $7.78 \times 10^{8}$ & 0.22 & 0.34 & 0.56 \\
\hline
\end{tabular}


The regions with the highest total value of wet $\mathrm{Mg}^{2+}$ deposition ranked: (1) Southeast $(\$ 4.29 \mathrm{M})$, (2) Midwest (\$3.72M), and (3) South Central (\$3.34M) (Table 6). The regions with the highest area-normalized total mean value of wet atmospheric $\mathrm{Mg}^{2+}$ deposition $\left(\$ \mathrm{ha}^{-1}\right)$ ranked: (1) Southeast $\left(\$ 0.04 \mathrm{ha}^{-1}\right),(2)$ East $\left(\$ 0.03 \mathrm{ha}^{-1}\right)$, and (3) Midwest $\left(\$ 0.03 \mathrm{ha}^{-1}\right)$ (Table 6).

The regions, Southeast $\left(\$ 0.04 \mathrm{ha}^{-1}\right)$ and East $\left(\$ 0.03 \mathrm{ha}^{-1}\right)$, ranked 1st and 2nd, respectively, for U.S. dollars per hectare of wet atmospheric $\mathrm{Mg}^{2+}$ deposition due to the regions' adjacency to the ocean. The Midwest $\left(\$ 0.03 \mathrm{ha}^{-1}\right)$ region ranked 3rd for U.S. dollar per hectare of wet atmospheric $\mathrm{Mg}^{2+}$ deposition, which might be driven by increased precipitation from the Great Lakes (Table 6).

\subsection{The Value of Annual Mean Dry $\mathrm{Mg}^{2+}$ Deposition at the Country Scale by State, Region (2000-2015)}

The total provisioning ecosystem value of atmospheric dry magnesium deposition flows was $\$ 28.2 \mathrm{M}$ (i.e., 28.2 million U.S. dollars). The states with the highest total value of dry atmospheric $\mathrm{Mg}^{2+}$ deposition ranked: (1) Texas (\$5.55M), (2) California (\$1.78M), and (3) Florida (\$1.51M) (Table 6). The states with the highest area-normalized total mean value of dry atmospheric $\mathrm{Mg}^{2+}$ deposition $\left(\$ \mathrm{ha}^{-1}\right.$ ) ranked: (1) Florida $\left(\$ 0.11 \mathrm{ha}^{-1}\right),(2)$ Texas $\left(\$ 0.08 \mathrm{ha}^{-1}\right)$ and (3) Louisiana $\left(\$ 0.08 \mathrm{ha}^{-1}\right)$ (Table 6).

The regions with the highest total value of dry $\mathrm{Mg}^{2+}$ deposition ranked: (1) South Central (\$7.34M), (2) West $(\$ 6.85 \mathrm{M})$, and (3) Southeast $(\$ 4.59 \mathrm{M})$ (Table 6). The regions with the highest area-normalized total mean value of dry atmospheric $\mathrm{Mg}^{2+}$ deposition $\left(\$ \mathrm{ha}^{-1}\right)$ ranked: (1) South Central $\left(\$ 0.07 \mathrm{ha}^{-1}\right)$, (2) Southeast $\left(\$ 0.04 \mathrm{ha}^{-1}\right)$, and (3) Midwest $\left(\$ 0.04 \mathrm{ha}^{-1}\right)$ (Table 6).

\subsection{The Value of Average Annual Total $\mathrm{Mg}^{2+}$ Deposition at the Country Scale by State, Region (2000-2015)}

The total provisioning ecosystem value of atmospheric magnesium deposition flows was $\$ 46.7 \mathrm{M}$ (i.e., 46.7 million U.S. dollars). The states with the highest total value of total atmospheric $\mathrm{Mg}^{2+}$ deposition ranked: (1) Texas $(\$ 7.37 \mathrm{M})$, (2) Florida (\$2.52M), and (3) California (\$2.34M) (Table 6). The states with the highest area-normalized total mean value of total atmospheric $\mathrm{Mg}^{2+}$ deposition $\left(\$ \mathrm{ha}^{-1}\right.$ ) ranked: (1) Florida $\left(\$ 0.18 \mathrm{ha}^{-1}\right)$, (2) Louisiana $\left(\$ 0.13 \mathrm{ha}^{-1}\right)$, and (3) Texas $\left(\$ 0.11 \mathrm{ha}^{-1}\right)$ (Table 6).

The regions with the highest total value of total $\mathrm{Mg}^{2+}$ deposition ranked: (1) South Central $(\$ 10.7 \mathrm{M}),(2)$ West $(\$ 9.89 \mathrm{M})$, and (3) Southeast $(\$ 8.88 \mathrm{M})$ (Table 6). The regions with the highest area-normalized mean value of total atmospheric $\mathrm{Mg}^{2+}$ deposition $\left(\$ \mathrm{ha}^{-1}\right)$ ranked: (1) South Central $\left(\$ 0.10 \mathrm{ha}^{-1}\right),(2)$ Southeast $\left(\$ 0.08 \mathrm{ha}^{-1}\right)$, and (3) Midwest $\left(\$ 0.07 \mathrm{ha}^{-1}\right)$ (Table 6).

\subsection{Implications for Ecosystem Services}

The atmosphere is a common-pool resource that plays an important role in the pedosphere in various aspects (e.g., climate regulation, nutrient deposition, etc.) The atmosphere provides inherent abiotic services [23] that are both related and analogous to geosystem services, with abiotic processes (e.g., weathering) providing nutrients that can be key to biotic productivity [21].

It is important to note that $\mathrm{Mg}^{2+}$ mined as a geosystem service can be partially substituted by atmospheric deposition [27]. Atmospheric deposition of nutrients have typically been excluded in a similar way to how abiotic subservice processes have been often omitted from the ES approach [23]. In $\mathrm{Mg}^{2+}$-limited areas, atmospheric deposition can augment the pedosphere and lithosphere services [27] with $\mathrm{Mg}^{2+}$ additions. The monetary value of atmospheric deposition is often unidentified in the market due to lack of information and/or knowledge of the valuation method (Table 7). This study demonstrates the value of atmospheric magnesium deposition flows entering the soil (pedosphere). In this case, according to Thornes et al. (2010) [28], atmospheric magnesium deposition flows fall into one of the twelve atmospheric services, which is ranked in the sixth place in value: "6. Direct use of the atmosphere for ecosystems and agriculture (service type: provisioning and supporting)", and can be valued based on market valuation using replacement cost method based on market-based value of commodities (price of agricultural dolomite $\left(\mathrm{CaMg}\left(\mathrm{CO}_{3}\right)_{2}\right)[16]$ if soil $\mathrm{pH}$ needs to be raised). 
Table 6. Total value and area-averaged value of annual mean atmospheric $\mathrm{Mg}^{2+}$ deposition for each state (region) for the 16-year period 2000 to 2015 based on a 2014 U.S. average price of $\$ 12.90$ per U.S. ton of agricultural dolomite $\left(\mathrm{CaMg}\left(\mathrm{CO}_{3}\right)_{2}\right)$ [16]. Note that some total values do not exactly equal the sum of their corresponding wet plus dry values due to roundoff errors.

\begin{tabular}{|c|c|c|c|c|c|c|}
\hline \multirow{2}{*}{ State (Region) } & \multicolumn{2}{|c|}{ Wet $\mathrm{Mg}^{2+}$ Deposition } & \multicolumn{2}{|c|}{ Dry $\mathrm{Mg}^{2+}$ Deposition } & \multicolumn{2}{|c|}{ Total $\mathrm{Mg}^{2+}$ Deposition } \\
\hline & $\begin{array}{c}\text { Mean Value } \\
\left(\$ h^{-1}\right)\end{array}$ & $\begin{array}{c}\text { Total Value } \\
\text { (\$) }\end{array}$ & $\begin{array}{c}\text { Mean Value } \\
\left(\$ h^{-1}\right)\end{array}$ & $\begin{array}{c}\text { Total Value } \\
\text { (\$) }\end{array}$ & $\begin{array}{c}\text { Mean Value } \\
\left(\$ h^{-1}\right)\end{array}$ & $\begin{array}{c}\text { Total Value } \\
\text { (\$) }\end{array}$ \\
\hline Connecticut & 0.06 & $8.05 \times 10^{4}$ & 0.04 & $4.79 \times 10^{4}$ & 0.10 & $1.28 \times 10^{5}$ \\
\hline Delaware & 0.06 & $3.07 \times 10^{4}$ & 0.05 & $2.39 \times 10^{4}$ & 0.10 & $5.45 \times 10^{4}$ \\
\hline Massachusetts & 0.05 & $1.03 \times 10^{5}$ & 0.05 & $9.37 \times 10^{4}$ & 0.09 & $1.96 \times 10^{5}$ \\
\hline Maryland & 0.04 & $9.66 \times 10^{4}$ & 0.04 & $9.38 \times 10^{4}$ & 0.08 & $1.90 \times 10^{5}$ \\
\hline Maine & 0.03 & $2.35 \times 10^{5}$ & 0.03 & $2.37 \times 10^{5}$ & 0.06 & $4.72 \times 10^{5}$ \\
\hline New Hampshire & 0.03 & $6.23 \times 10^{4}$ & 0.02 & $5.94 \times 10^{4}$ & 0.05 & $1.22 \times 10^{5}$ \\
\hline New Jersey & 0.06 & $1.20 \times 10^{5}$ & 0.04 & $8.54 \times 10^{4}$ & 0.11 & $2.05 \times 10^{5}$ \\
\hline New York & 0.02 & $2.81 \times 10^{5}$ & 0.02 & $3.13 \times 10^{5}$ & 0.05 & $5.94 \times 10^{5}$ \\
\hline Pennsylvania & 0.03 & $2.94 \times 10^{5}$ & 0.03 & $3.70 \times 10^{5}$ & 0.06 & $6.64 \times 10^{5}$ \\
\hline Rhode Island & 0.06 & $1.58 \times 10^{4}$ & 0.05 & $1.24 \times 10^{4}$ & 0.11 & $2.82 \times 10^{4}$ \\
\hline Vermont & 0.02 & $4.64 \times 10^{4}$ & 0.02 & $5.56 \times 10^{4}$ & 0.04 & $1.02 \times 10^{5}$ \\
\hline West Virginia & 0.02 & $1.33 \times 10^{5}$ & 0.04 & $2.27 \times 10^{5}$ & 0.06 & $3.60 \times 10^{5}$ \\
\hline (East) & 0.03 & $1.50 \times 10^{6}$ & 0.03 & $1.62 \times 10^{6}$ & 0.06 & $3.12 \times 10^{6}$ \\
\hline Iowa & 0.04 & $5.30 \times 10^{5}$ & 0.04 & $5.80 \times 10^{5}$ & 0.08 & $1.11 \times 10^{6}$ \\
\hline Illinois & 0.04 & $5.17 \times 10^{5}$ & 0.05 & $6.63 \times 10^{5}$ & 0.08 & $1.18 \times 10^{6}$ \\
\hline Indiana & 0.04 & $3.53 \times 10^{5}$ & 0.04 & $3.61 \times 10^{5}$ & 0.08 & $7.14 \times 10^{5}$ \\
\hline Michigan & 0.03 & $4.14 \times 10^{5}$ & 0.04 & $5.84 \times 10^{5}$ & 0.07 & $9.98 \times 10^{5}$ \\
\hline Minnesota & 0.03 & $5.74 \times 10^{5}$ & 0.03 & $6.13 \times 10^{5}$ & 0.05 & $1.19 \times 10^{6}$ \\
\hline Missouri & 0.03 & $5.78 \times 10^{5}$ & 0.03 & $4.62 \times 10^{5}$ & 0.06 & $1.04 \times 10^{6}$ \\
\hline Ohio & 0.03 & $3.09 \times 10^{5}$ & 0.04 & $4.08 \times 10^{5}$ & 0.07 & $7.17 \times 10^{5}$ \\
\hline Wisconsin & 0.03 & $4.46 \times 10^{5}$ & 0.04 & $6.13 \times 10^{5}$ & 0.07 & $1.06 \times 10^{6}$ \\
\hline (Midwest) & 0.03 & $3.72 \times 10^{6}$ & 0.04 & $4.28 \times 10^{6}$ & 0.07 & $8.01 \times 10^{6}$ \\
\hline Arkansas & 0.03 & $4.49 \times 10^{5}$ & 0.03 & $4.12 \times 10^{5}$ & 0.06 & $8.61 \times 10^{5}$ \\
\hline Louisiana & 0.05 & $6.09 \times 10^{5}$ & 0.08 & $8.91 \times 10^{5}$ & 0.13 & $1.50 \times 10^{6}$ \\
\hline Oklahoma & 0.03 & $4.64 \times 10^{6}$ & 0.03 & $4.87 \times 10^{5}$ & 0.05 & $9.51 \times 10^{5}$ \\
\hline Texas & 0.03 & $1.82 \times 10^{6}$ & 0.08 & $5.55 \times 10^{6}$ & 0.11 & $7.37 \times 10^{6}$ \\
\hline (South Central) & 0.03 & $3.34 \times 10^{6}$ & 0.07 & $7.34 \times 10^{6}$ & 0.10 & $1.07 \times 10^{7}$ \\
\hline Alabama & 0.04 & $5.42 \times 10^{5}$ & 0.03 & $4.07 \times 10^{5}$ & 0.07 & $9.49 \times 10^{5}$ \\
\hline Florida & 0.07 & $1.01 \times 10^{6}$ & 0.11 & $1.51 \times 10^{6}$ & 0.18 & $2.52 \times 10^{6}$ \\
\hline Georgia & 0.04 & $5.59 \times 10^{5}$ & 0.03 & $5.03 \times 10^{5}$ & 0.07 & $1.06 \times 10^{6}$ \\
\hline Kentucky & 0.03 & $2.61 \times 10^{5}$ & 0.02 & $2.60 \times 10^{5}$ & 0.05 & $5.21 \times 10^{5}$ \\
\hline Mississippi & 0.04 & $5.24 \times 10^{5}$ & 0.04 & $4.45 \times 10^{5}$ & 0.08 & $9.69 \times 10^{5}$ \\
\hline North Carolina & 0.04 & $4.80 \times 10^{5}$ & 0.05 & $5.80 \times 10^{5}$ & 0.08 & $1.06 \times 10^{6}$ \\
\hline South Carolina & 0.04 & $3.48 \times 10^{5}$ & 0.04 & $2.85 \times 10^{5}$ & 0.08 & $6.33 \times 10^{5}$ \\
\hline Tennessee & 0.03 & $2.89 \times 10^{5}$ & 0.03 & $2.75 \times 10^{5}$ & 0.05 & $5.64 \times 10^{5}$ \\
\hline Virginia & 0.03 & $2.72 \times 10^{5}$ & 0.03 & $3.26 \times 10^{5}$ & 0.06 & $5.97 \times 10^{5}$ \\
\hline (Southeast) & 0.04 & $4.29 \times 10^{6}$ & 0.04 & $4.59 \times 10^{6}$ & 0.08 & $8.87 \times 10^{6}$ \\
\hline Colorado & 0.01 & $3.28 \times 10^{5}$ & 0.02 & $6.56 \times 10^{5}$ & 0.04 & $9.83 \times 10^{5}$ \\
\hline Kansas & 0.02 & $4.69 \times 10^{5}$ & 0.02 & $4.74 \times 10^{5}$ & 0.04 & $9.43 \times 10^{5}$ \\
\hline Montana & 0.01 & $3.97 \times 10^{5}$ & 0.02 & $6.72 \times 10^{5}$ & 0.03 & $1.07 \times 10^{6}$ \\
\hline North Dakota & 0.02 & $3.93 \times 10^{5}$ & 0.02 & $4.57 \times 10^{5}$ & 0.04 & $8.50 \times 10^{5}$ \\
\hline Nebraska & 0.02 & $3.74 \times 10^{5}$ & 0.02 & $3.86 \times 10^{5}$ & 0.04 & $7.60 \times 10^{5}$ \\
\hline South Dakota & 0.02 & $3.66 \times 10^{5}$ & 0.02 & $3.84 \times 10^{5}$ & 0.04 & $7.50 \times 10^{5}$ \\
\hline Wyoming & 0.01 & $2.69 \times 10^{5}$ & 0.02 & $4.99 \times 10^{5}$ & 0.03 & $7.68 \times 10^{5}$ \\
\hline (Northern Plains) & 0.02 & $2.60 \times 10^{6}$ & 0.02 & $3.53 \times 10^{6}$ & 0.04 & $6.12 \times 10^{6}$ \\
\hline Arizona & 0.01 & $3.07 \times 10^{5}$ & 0.04 & $1.11 \times 10^{6}$ & 0.05 & $1.41 \times 10^{6}$ \\
\hline California & 0.01 & $5.58 \times 10^{5}$ & 0.04 & $1.78 \times 10^{6}$ & 0.06 & $2.34 \times 10^{6}$ \\
\hline Idaho & 0.01 & $2.63 \times 10^{5}$ & 0.02 & $3.95 \times 10^{5}$ & 0.03 & $6.58 \times 10^{5}$ \\
\hline New Mexico & 0.01 & $3.19 \times 10^{5}$ & 0.03 & $9.88 \times 10^{5}$ & 0.04 & $1.31 \times 10^{6}$ \\
\hline Nevada & 0.01 & $1.94 \times 10^{5}$ & 0.03 & $8.24 \times 10^{5}$ & 0.04 & $1.02 \times 10^{6}$ \\
\hline Oregon & 0.02 & $5.06 \times 10^{5}$ & 0.02 & $6.10 \times 10^{5}$ & 0.04 & $1.12 \times 10^{6}$ \\
\hline Utah & 0.02 & $3.76 \times 10^{5}$ & 0.03 & $7.49 \times 10^{5}$ & 0.05 & $1.13 \times 10^{6}$ \\
\hline Washington & 0.03 & $5.12 \times 10^{5}$ & 0.02 & $3.98 \times 10^{5}$ & 0.05 & $9.10 \times 10^{5}$ \\
\hline (West) & 0.01 & $3.04 \times 10^{6}$ & 0.03 & $6.85 \times 10^{6}$ & 0.05 & $9.89 \times 10^{6}$ \\
\hline Totals or averages & 0.02 & $1.85 \times 10^{7}$ & 0.04 & $2.82 \times 10^{7}$ & 0.06 & $4.67 \times 10^{7}$ \\
\hline
\end{tabular}


Table 7. Atmosphere-pedosphere ecosystem services exchange, stocks, goods, flows (represented by arrows), and ownership in relation to atmospheric magnesium deposition.

\begin{tabular}{|c|c|}
\hline Atmosphere & Pedosphere \\
\hline $\begin{array}{l}\text { Atmospheric } \mathrm{Mg}^{2+} \\
\text { stock }\end{array}$ & Soil-based $\mathrm{Mg}^{2+}$ stock \\
\hline & Ownership \\
\hline $\begin{array}{l}\text { Common-pool } \\
\text { resource }\end{array}$ & Mixed (e.g., government, private) \\
\hline \multicolumn{2}{|c|}{ The market information } \\
\hline $\begin{array}{l}\text { Unidentified } \\
\text { market value }\end{array}$ & $\begin{array}{c}\text { Partially identified market value } \\
\text { (e.g., replacement cost) }\end{array}$ \\
\hline \multicolumn{2}{|c|}{ The degree of market information availability } \\
\hline $\begin{array}{l}\text { Little or no market } \\
\text { information }\end{array}$ & Partial market information \\
\hline
\end{tabular}

Agricultural sector is one of many beneficiaries of atmospheric magnesium deposition entering soil [29]. Agriculture uses atmospheric magnesium deposition flows (common-pool resource) and pedospheric magnesium flows (mixed ownership), and transforms them into agricultural goods and services (Table 7, Figure 2) [29]. They are part of numerous atmosphere-pedosphere ecosystems flows, which provide both provisioning (e.g., food), and supporting (e.g., nutrient cycling) ecosystem services to agriculture for further transformation into commodities (primary agricultural products) (Figure 2). One of the advantages of atmospheric wet $\mathrm{Mg}^{2+}$ deposition is that it is readily available as a plant nutrient [21].

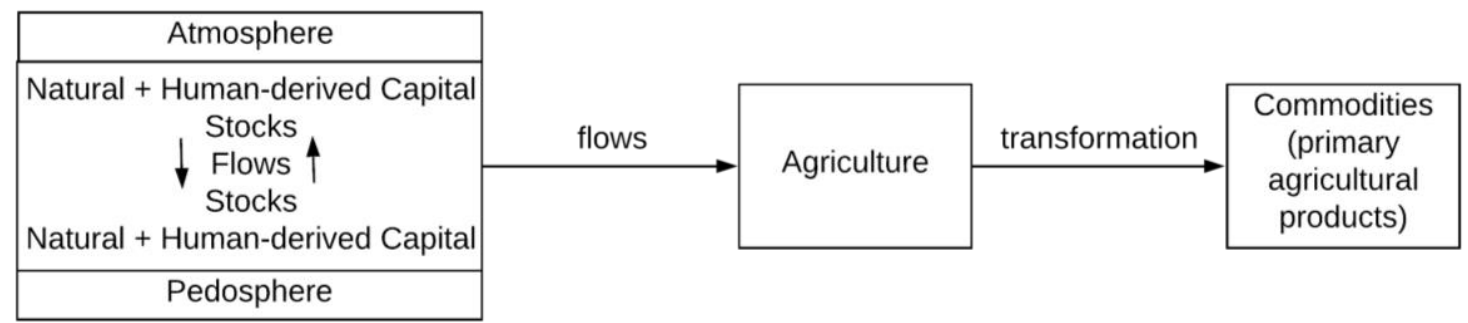

Figure 2. The building blocks of a systems approach to describing atmosphere and pedosphere ecosystem services exchange (based on [6]) from which agriculture receives ecosystem services (e.g., supporting: nutrient cycling, etc.) flows, and transforms them into agricultural commodities.

Atmospheric magnesium deposition flows have different values within states and regions. They differ by type: "natural" and "human-derived" (e.g., marine: sea-salt aerosols; terrestrial: soil dust, biological emissions; anthropogenic: industrial, biomass burning) [13]. In this study, the maps show the spatial structure (or geographic extent) of where the flow is delivering its "goods" with a high level of spatial accuracy, but the sources of flows (e.g., locally-derived versus long distance transport), and their temporal structure (e.g., seasonality) are unknown [6]. Soil is a non-renewable resource on a human timescale and atmospheric deposition serves as a source of potential replenishment of plant nutrients in the soil and can have cumulative benefits over time [21]. The results of this study show that the hydrosphere may be an important source of $\mathrm{Mg}^{2+}$ as indicated by higher deposition values in proximity to oceans. In this case, the hydrosphere may provide ES at a faster rate at a large spatial scale compared to pedosphere and lithosphere weathering [21]. Loess cover (Figure 1) is another source and pathway for $\mathrm{Mg}^{2+}$ distribution and delivery within the landscape.

Boundary-based administrative accounts rely on a "crisp" boundary [30] mapping approach instead of depicting cross-border flows (Figure 1). These monetary values of atmospheric magnesium 
deposition flows lack error assessment or uncertainty evaluation [30]. In addition, atmospheric magnesium contributions can vary in value and their effects on soil depending on the type of "human-derived" materials they are being compared to, for example: agricultural dolomite (raises soil $\mathrm{pH}$ ) versus agricultural Epsom salts (no increase in soil $\mathrm{pH}$ ). This study used the average price of agricultural dolomite for the country, however, a more detailed analysis would enhance valuation with a more detailed information for a particular state (e.g., most suitable human-derived materials to use, transportation costs, etc.).

\section{Conclusions}

Ecosystem services from the atmospheric magnesium deposition flows (wet, dry, and total), which can be considered a naturally occurring liming and fertilizer materials, have not been included in economic valuations of ecosystem services. This represents an example of a "nature-based" addition, in contrast to "human-derived" nutrient materials [27]. This study demonstrated the market valuation of atmospheric magnesium deposition in the USA within science-based boundaries (e.g., soil order), and administrative boundaries (e.g., state, region) based on liming replacement costs. Estimated total and area-averaged values of annual mean atmospheric $\mathrm{Mg}^{2+}$ deposition are important in diminishing the reliance on external fertilizer and liming inputs. Cost-effective policy incentives for land-users require such estimates in order to demonstrate the benefit of atmospheric magnesium deposition in maximizing profit while minimizing the expenses associated with liming and fertilization. At the field scale soil nutrient testing can be used to quantify the economic value and benefit of atmospheric $\mathrm{Mg}^{2+}$ deposition. The value of atmospheric magnesium deposition flows (separate constituent, composite) are spatially and temporally heterogeneous. Future research on atmospheric magnesium deposition flows, and ecosystems services should quantify how much of these potential ecosystem flows are actually being realized (e.g., utilized by crops). This study is an important contribution to understanding supply of atmospheric magnesium deposition flows to the SDGs and a global system for monitoring ecosystem services change in the uncertain times of climate change. Future research should also consider the synergistic impact of both abiotic and biotic services on ecosystem functioning and the resulting economic benefits [31].

Author Contributions: Conceptualization, E.A.M.; methodology, G.R.G., M.A.S. and L.Z.; writing-original draft preparation, G.R.G. and E.A.M.; writing-review and editing, G.R.G., E.A.M., C.J.P., M.A.S. and L.Z.; visualization, M.P.C. and C.J.P.

Funding: This research received no external funding.

Acknowledgments: This study was based on data from the National Atmospheric Deposition Program (NRSP-(3). We would like to thank the reviewers for their constructive comments and suggestions.

Conflicts of Interest: The authors declare no conflict of interest.

\section{References}

1. Millennium Ecosystem Assessment. Ecosystems and Human Well-Being: Synthesis; Millennium Ecosystem Assessment Series; World Resources Institute: Washington, DC, USA, 2005; p. 155.

2. Costanza, R.; d'Arge, R.; Groot, R.; Farber, S.; Grasso, M.; Hannon, B.; Limburg, K.; Naeem, S.; O’Neill, R.V.; Paruelo, J.; et al. The value of the world's ecosystem services and natural capital. Nature 1997, 387, $253-260$. [CrossRef]

3. Wood, S.L.; Jones, S.K.; Johnson, J.A.; Brauman, K.A.; Chaplin-Kramer, R.; Fremier, A.; Girvetz, E.; Gordon, L.J.; Kappel, C.V.; Mandle, L.; et al. Distilling the role of ecosystem services in the sustainable development goals. Ecosyst. Serv. 2017, 29, 70-82. [CrossRef]

4. Heal, G. Valuing ecosystem services. Ecosyst. 2000, 3, 24-30. [CrossRef]

5. Field, J.P.; Breshears, D.D.; Law, D.J.; Villegas, C.; López-Hoffman, L.; Brooks, P.D.; Chorover, J.; Pelletier, J.D. Understanding ecosystem services from a geosciences perspective. Eos 2016, 97. [CrossRef] 
6. Jones, L.; Norton, L.; Austin, Z.; Browne, A.L.; Donovan, D.; Emmett, B.A.; Grabowski, Z.J.; Howard, D.C.; Jones, J.P.G.; Kenter, J.O.; et al. Stocks and flows of natural and human-derived capital in ecosystem services. Land Use Policy 2016, 52, 151-162. [CrossRef]

7. Mikhailova, E.A.; Post, C.J.; Schlautman, M.A.; Groshans, G.R.; Cope, M.P.; Zhang, L. A systems-based approach to ecosystem services valuation of various atmospheric calcium deposition flows. Resources 2019, 8, 66. [CrossRef]

8. Keestra, S.D.; Bouma, J.; Wallinga, J.; Tittonell, P.; Smith, P.; Cerda, A.; Montanarella, L.; Quinton, J.N.; Pachepsky, Y.; Van der Putten, W.H.; et al. The significance of soils and soil science towards realization of the United Nations Sustainable Development Goals. Soil 2016, 2, 111-128. [CrossRef]

9. Mikkelsen, R. Soil and fertilizer magnesium. Better Crop. 2010, 94, 26-28.

10. Senbayram, M.; Gransee, A.; Wahle, V.; Thiel, H. Role of magnesium fertilizers in agriculture: Plant-Soil continuum. Crop Pasture Sci. 2015, 66, 1219-1229. [CrossRef]

11. Cakmak, I. Magnesium in crop production, food quality and human health. Plant Soil. 2013, 368, 1-4. [CrossRef]

12. Nielsen, F.H. Importance of plant sources of magnesium for human health. Crop Pasture Sci. 2015, 66, 1259-1264. [CrossRef]

13. Berner, E.K.; Berner, R.A. Global Environment: Water, Air, and Geochemical Cycles, 2nd ed.; Princeton University Press: Princeton, NJ, USA, 1996.

14. Kisters, K.; Grober, U. Magnesium in health and disease. Plant Soil. 2013, 368, 155-165. [CrossRef]

15. Groshans, G.; Mikhailova, E.; Post, C.; Schlautman, M.; Cope, M.; Zhang, L. Contribution of atmospheric deposition to soil provisioning ecosystem services in the contiguous United States: Part. 2. Magnesium. In Proceedings of the 3rd International Conference on Atmospheric Dust-DUST 2018, Bari, Italy, 14 December 2018; pp. 52-57.

16. Minerals Yearbook, 2014: Stone, crushed [Advance Release]; U.S. Department of the Interior, U.S. Geological Survey: Virgina, VA, USA, April 2016. Available online: https://minerals.usgs.gov/minerals/pubs/commodity/ stone_crushed/myb1-2014-stonc.pdf (accessed on 20 July 2019).

17. Goddard, M.A.; Mikhailova, E.A.; Post, C.J.; Schlautman, M.A. Atmospheric $\mathrm{Mg}^{2+}$ wet deposition within the continental U.S. in relation to soil inorganic carbon sequestration. Tellus 2007, 59B, 50-56. [CrossRef]

18. Connolly, S.J.; Cain, T.C.; Vestal, J.S.; Edwards, P.J. The potential effects of acid deposition: What's a National Forest to do? Advancing the Fundamental Sciences. In Proceedings of the Forest Service National Earth Sciences Conference, San Diego, CA, USA, 18-22 October 2004; pp. 428-437. Available online: http://citeseerx.ist.psu.edu/viewdoc/download?doi=10.1.1.297.6318\&rep=rep1\&type=pdf\#page=158 (accessed on 20 July 2019).

19. Draaijers, G.P.J.; Van Leeuwen, E.P.; De Jong, P.G.H.; Erisman, J.W. Base-cation deposition in Europe-Part II. Acid neutralization capacity and contribution to forest nutrition. Atmos. Environ. 1997, 31, 4159-4168. [CrossRef]

20. Watmough, S.A.; Whitfield, C.J.; Fenn, M.E. The importance of atmospheric base cation deposition for preventing soil acidification in the Athabasca Oil Sands Region of Canada. Sci. Total Environ. 2014, 493, 1-11. [CrossRef] [PubMed]

21. Van Ree, C.C.D.F.; Van Beukering, P.J.H. Geosystem services: A concept in support of sustainable development of the subsurface. Ecosyst. Serv. 2016, 20, 30-36. [CrossRef]

22. National Atmospheric Deposition Program (NRSP-(3); NADP Program Office, Wisconsin State Laboratory of Hygiene: Madison, WI, USA, 2018. Available online: http://nadp.slh.wisc.edu/ (accessed on 20 July 2019).

23. Gray, M. The confused position of the geosciences within the "natural capital" and "ecosystem services" approaches. Ecosyst. Serv. 2018, 34, 106-112. [CrossRef]

24. Reith, J.S. The magnesium contents of soils and crops. J. Sci. Ed. Agric. 1963, 14, 417-426. [CrossRef]

25. Groshans, G.; Mikhailova, E.; Post, C.; Schlautman, M.; Zurqani, H.; Zhang, L. Assessing the value of soil inorganic carbon for ecosystem services in the contiguous United States based on liming replacement costs. Land 2018, 7, 149. [CrossRef]

26. ArcGIS Desktop: Release, version 10.4; Environmental Systems Research Institute: Redlands, CA, USA, 2016.

27. Van Ree, C.C.D.F.; Van Beukering, P.J.H.; Boekestijn, J. Geosystem services: A hidden link in ecosystem management. Ecosyst. Serv. 2017, 26, 58-69. [CrossRef] 
28. Thornes, J.; Bloss, W.; Bouzarovski, S.; Cai, X.; Chapman, L.; Clark, J.; Dessai, S.; Du, S.; van der Horst, D.; Kendall, M.; et al. Communicating the value of atmospheric services. Meteorol. Appl. 2010, 17, 243-250. [CrossRef]

29. Swinton, S.M.; Lupi, F.; Robertson, G.P.; Hamilton, S.K. Ecosystem services and agriculture: Cultivating agricultural ecosystems for diverse benefits. Ecol. Econ. 2007, 64, 245-252. [CrossRef]

30. Grunwald, S.; Thompson, J.A.; Boettinger, J.L. Digital soil mapping and modeling at continental scales: Finding solutions to global issues. Soil Sci. Soc. Am. J. 2011, 75, 1201-1213. [CrossRef]

31. Brouwer, R.; Brander, L.; Kuik, O.; Papyrakis, E.; Bateman, I. A Synthesis of Approaches to Assess and Value Ecosystem Services in the EU in the Context of TEEB; TEEB Follow-up Study for Europe; VU University Amsterdam: Amsterdam, The Netherlands, May 2013; Available online: http://ec.europa.eu/environment/ nature/biodiversity/economics/pdf/EU\%20Valuation.pdf (accessed on 20 July 2019).

C 2019 by the authors. Licensee MDPI, Basel, Switzerland. This article is an open access article distributed under the terms and conditions of the Creative Commons Attribution (CC BY) license (http://creativecommons.org/licenses/by/4.0/). 